\title{
Legal Position of Land and Buildings Acquisition Duty in the Process of Making Deed of Transfer of Rights
}

\author{
Abet Maulana Hakim Salim H.S Arba \\ Notary Master Study Program, Faculty of Law, University of Mataram, Indonesia
}

\begin{abstract}
The existence of provisions in the PDRD Law on PPAT can only sign a deed of transfer of land rights after proof of tax payment, making PPAT faced with a complicated situation that indirectly PPAT is required to ensure that the taxes related to the transfer of land and /or buildings have been paid. This study aims to analyze the legal position of BPHTB in the process of making a deed of transfer of rights and to analyze the legal implications of the unpaid BPHTB in the process of making a deed of transfer of rights. The issues discussed in this study include: the legal position of BPHTB in the process of making a deed of transfer of rights and about the legal implications of the unpaid BPHTB in the process of making the Deed of Transfer of Rights. This research is normative legal research with the aim to know the legal position of BPHTB in the process of making a deed of transfer of rights. The approach used is a statutory approach and a conceptual approach. The technique of collecting legal materials used is to conduct literature studies, namely by conducting an assessment of library materials using a recording system, then analyzed with an expanded interpretation of the law (extensive interpretation). Based on the results of the study, it can be concluded that the legal position of BPHTB in the process of making a deed of transfer of rights is as one of the requirements of the procedure, not an absolute requirement in the creation of a deed of transfer of rights because it is not included in the material requirements or formal in the making of the deed. The unpaid BPHTB in the process of making a deed of transfer of rights caused the registration of the transfer of rights at the land office could not be further processed and the PPAT that made the deed of transfer of rights threatened the imposition of administrative sanctions in the form of fines. Keywords: BPHTB, deed, transfer of rights
\end{abstract}

DOI: $10.7176 / \mathrm{JLPG} / 112-06$

Publication date:August $31^{\text {st }} 2021$

\section{INTRODUCTION}

To assure legal certainty to the parties who commit legal acts on land and buildings, the state has regulated explicitly by making the provisions outlined in the legislation related to land registration as mandated in Article 19 paragraph (1) of Law No. 5 of 1960 (Statute Book of 1960 No. 104, Supplement to Statute Book No. 2043) which is hereinafter known as agrarian basic law (UUPA) which in the article expressly stated that "To guarantee legal certainty by The government held land registration in all regions of the Republic of Indonesia according to the provisions stipulated by the Government Regulation."

The Law's mandate is then regulated in Government Regulation No. 10 of 1961 concerning Land Registration which is then revoked and replaced by Government Regulation No. 24 of 1997 concerning Land Registration.

Concerning this matter specifically concerning the rules of implementation of the Law on the transfer of land rights further explained by Marihot P. Siahaan, that in Article 37 of Government Regulation No. 24 of 1997 it is determined that the transfer of land rights and property rights to units of flats through buying and selling, exchanging, grants, income in the company and other legal acts of transfer of rights, except the transfer of rights through auctions, can only be proven by a deed made by the Authorized Land Deed Official (PPAT) in accordance with the provisions of the prevailing Laws and Regulations. PPAT is a public official who is given the authority to make authentic deeds in certain legal acts concerning flat units' land rights or property rights. The regulation on the position of PPAT is stipulated in Government Regulation No. 37 of 1998 concerning Regulation of the Office of the Land Deed Official (PP 37/1998). In the explanation of Article 3 paragraph 1 PP $37 / 1998$, the deed made by PPAT is an authentic deed made to prove the existence of specific legal actions that result in the transfer of rights to land and buildings.

In the transfer of property rights on land, the parties must submit proof of payment of tax payable, in the sense that the parties facing the PPAT have previously paid taxes owed.

Tax is the contribution of the people to the state treasury based on the law so that no direct repayment can impose it. Taxes are levied by the ruler based on legal norms to cover the cost of producing collective goods and services to achieve general welfare.(Widyaningsih, 2011)

One type of land tax is BPHTB, which is a tax imposed on every acquisition of land and building rights, either because of the transfer of rights from a private person /entity to a private person/other entity or because of the granting of new rights by the government/state to a private person/entity.(Siahaan, 2005)

In the Explanation of Article 96 paragraph (2) of Law No. 28 of 2009 concerning Local Tax and Regional 
Levy (Statute Book of 2009 No. 130, Supplement to Statute Book No. 5049) it can be seen that the BPHTB collection system is self-assessment, i.e., taxpayers are entrusted to calculate, take into account, pay, and selfreport the taxes owed using the Local Tax Return (SPTPD). It is reaffirmed in Article 3 paragraph (4) letter h of Government Regulation No. 55 of 2016 that the Type of District /City Tax paid by itself based on the Taxpayer's calculation is BPHTB.

Safri Nurmanu, in his book entitled Introduction to Taxation, explains that the Self-assessment System is a tax system in which the initiative to meet tax obligations is in the Taxpayer.(Nurmantu, 2005)

The characteristics of self-assessment system are:(Pudyatmoko, 2009)

a. The authority to determine the amount of tax owed is on the taxpayer himself;

b. Active taxpayers, from calculating, depositing and self-reporting taxes owed;

c. $\quad$ Fiscus does not interfere and only supervises.

Related to this, in article 90 paragraph (1) letter a Law No. 28 of 2009 concerning Local Tax and Regional Levy has been regulated provisions on when owed BPHTB tax for sale and purchase, namely from the date of creation and signing of the deed, then furthermore in paragraph (2) it is stated that the tax payable must be paid at the time of acquisition of rights as referred to in paragraph (1). Furthermore, in the Article governing the provisions for authorized officials in signing deed, minutes of auction and registration of rights, namely in Article 91 paragraph (1) it is determined that: "The Official of The Land Deed / Notary can only sign the deed of transfer of rights to land and / or buildings after the taxpayer submits proof of payment of taxes".

Based on the phrase "since" in the provisions of Article 90 paragraphs (1) and (2) above, it can be known that the appearance of tax payable if it has been made and signed deed, in the sense that the position of BPHTB is after the deed of transfer of rights has been made and signed, while in the phrase "can only sign" in the provisions of Article 91 paragraph (1) PDRD law can be understood that PPAT is prohibited from carrying out its authority to make a deed if the taxpayer has not made payment of BPHTB or the position of BPHTB is in before the deed of transfer of land rights made. Furthermore, related to PPAT that signed the deed before the payment of BPHTB get administrative sanctions as contained in the provisions of Article 93 paragraph (1), namely: where it is determined that the Land Deed Official / Notary and the Head of Office in charge of the state auction service, who violate the provisions as referred to in Article 91 paragraph (1) and paragraph (2) shall be subject to administrative sanctions in the form of a fine of $\mathrm{Rp} 7,500,000.00$ (seven million five hundred thousand rupiahs) for each violation. However, in article 91 paragraph (3) of the PDRD Law there is a similar provision for the Head of the District /City Office where it is stated that: "The Head of Land Office can only register the Right to land or the registration of land rights transfer after the Taxpayer submits proof of tax payment".

The author would like to examine further the legal position of BPHTB in the process of making a deed of transfer of rights. This research was conducted to find out the clarity of the position of BPHTB in the process of making a deed of transfer of rights according to Article 91 paragraph (1) of Law No. 28 of 2009 concerning Local Tax and Regional Levy (PDRD Law) where it is determined that "The Land Deed/Notary Official can only sign a deed of transfer of land and/or building rights after the taxpayer submits proof of tax payment", the provision does not appear to provide clarity on the position of BPHTB whether included as an absolute condition that determines the validity of a deed of transfer of rights or only limited to the terms of procedure. Based on the above, the author is interested in conducting research on the issue by formulating the title "Legal Position of Land and Building Acquisition Duty in the Process of Making a Deed of Transfer of Rights.".

Based on the background described above can be formulated the subject matter as follows:

1. What is the Legal Position of BPHTB in the Process of Making a Deed of Transfer of Rights?

2. How are the Legal Implications of BPHTB not paying off in the process of making the Deed of Transfer of Rights?

\section{RESEARCH METHOD}

The type of study used in this paper uses normative research, namely research with basislibrary based materials that focus on reading and studying primary and secondary legal materials to clearly describe the various matters related to the object being studied, namely a clear picture of the application of legislation policy so that it takes reasoning from the normative legal aspect to find the truth based on the legal logic from the normative side, in this case regarding the legal position of BPHTB in the creation of a deed of transfer of rights and legal implications of the non-payment of BPHTB in the process of making the Deed of Transition of Rights. The approach used in answering the problems that have been formulated is to use the statute approach, through this approach, researchers will study the laws and regulations related to the problem studied. Conceptual Approach, an approach that examines the concepts /views of experts related to BPHTB and the Act of Rights Transfer. The type of legal materials used in this study consists of primary and secondary legal materials obtained through direct research on legislation on BPHTB and the transfer of land rights and related literature, in this case by conducting literature studies, namely by conducting a review of library materials using a recording system. 


\section{DISCUSSION}

\subsection{Legal Position of BPHTB in the Process of Making Deed of Transfer of Rights}

Any legal action on the transfer of rights to land and buildings must be proven by a deed made by and before the PPAT, there is no sanction for the parties if the legal action of the transfer of rights is not done before the PPAT, but the transfer of rights cannot be followed up to be registered with the BPN so that the beneficiary will not get a certificate on his behalf. If there has previously been a transfer of rights under the hands, then the way that is done is to repeat the procedure of transfer of rights by making a deed before the PPAT, but this depends again on the initiative and awareness of the parties.

Terms of sale and purchase of land there are two, namely material terms and terms formal:(Sutedi, 2019) a. Material Terms

Material requirements determine the validity of the sale and purchase of the land, among others as follows:

1. The buyer has the right to purchase the land in question;

2. The seller has the right to sell the land in question;

3. The land rights in question may be traded and not in a state of dispute. Formal Requirement

After all material requirements are met, PPAT will make a deed of sale and purchase. Deed of sale and purchase according to Article 37 paragraph (1) government regulation No. 24 of 1997 concerning Land Registration must be made by PPAT. The sale and purchase conducted without the presence of PPAT remain valid because the UUPA is based on Customary Law (Article 5 UUPA), while in the Customary Law, the system used is a concrete system / cash / real. Nevertheless, in order to realize the existence of a legal certainty in every transfer of land rights, Government Regulation No. 24 of 1997 concerning Land Registration as the implementing regulation of the LAW has determined that any agreement intending to transfer land rights must be proven by a deed made by and before the PPAT.(Effendie, 1993)

PPAT Deed is an authentic deed, this is affirmed by Article 1 paragraph (1) and Article 3 paragraph (1) of Government Regulation No. 37 of 1998 concerning Regulation of the Office of the Land Deed Maker. As an authentic deed, the PPAT deed applies provisions on the terms and procedures for making an authentic deed. The form of authentic deed is determined by law, while the official who can make it inevitable that the exact weight must also be determined by legislation or legislation at the same level as the law.(Budiono, 2007)

As an authentic deed, PPAT deed as a means of proof with perfect evidentiary power can be degraded to the power of proof to be like a deed under the hand. Degradation of the power of authentic deed evidence into the force of evidence under the hands, and juridical defects of authentic deed resulting in an authentic deed can be canceled or null and void by law or nonexistent, occurring if there is a violation of the provisions of the legislation, namely:(Latumaten, 2009)

1. Article 1869 of the Civil Code states that a deed that because of incompetents or incompetents of the employee mentioned above or because of a defect in its form, cannot be applied as an authentic deed, but has power as a deed under the hands if signed by the parties.

The article contains a provision, that a deed has no authentic evidence strength and only has the power of evidence under the hands in the case of:

a. The General Officer is not authorized to make the deed;

b. The general officer is unable (incapable) to make a deed;

c. Defects in its shape.

2. Article 1320 of the Civil Code, which states that the validity of an agreement must be fulfilled, namely:

a. agree upon those who bind themselves;

b. the ability to make a covenant;

c. a particular thing;

d. You are halal.

Terms $\mathrm{a}$ and $\mathrm{b}$ are subjective terms because of the persons or subjects who make agreements and if the subjective terms are violated, then the deed can be resolved, while the terms $\mathrm{c}$ and $\mathrm{d}$ are objective terms because of the content of the agreement and if the objective terms are violated then the deed is null and void.

According to Herlien Budiono, the causes of limitations include incompetence, indecency, the form of the agreement being challenged, the content of the agreement contrary to the law, the implementation of the agreement contrary to the law, the motivation of making an agreement contrary to the law, the agreement contrary to public order and the decency of good, defects in will and abuse of circumstances.

The transfer of land rights that are not done in the presence of PPAT is not sanctioned for the parties, but the parties will encounter practical difficulties i.e., the beneficiary will not be able to register the transfer of rights so that it will not get a certificate on its behalf. Therefore, the path that can be taken is to repeat the procedure of transfer of rights in the presence of PPAT. However, this method depends on the willingness of the parties. Difficulties will arise when the first party or its heirs refuse or have moved elsewhere so that the repetition of the legal action of the transition can not be done.(Soedjendro, 2001)

PPAT Act related to the need for juridische levering in addition to the real submission (feitelijk levering). 
The obligation to submit a certificate of property on land sold is very important, therefore Article 1482 of the Civil Code states, "The obligation to hand over an item includes everything that becomes its equipment and is intended for its permanent use, along with the letters of proof of property, if it exists". So the surrender of a field of land includes the surrender of its certificate.(Harahap, 1986)

Based on Government Regulation No. 24 of 1997 concerning Land Registration, the transfer of land and objects on it is carried out by deed of PPAT. Transfer of land from the owner to the recipient is accompanied by a juridische levering, i.e. submission that must meet the formalities of the law, including eligibility; performed through established procedures; using documents; created by/in the presence of PPAT.(Abdulkadir, 1994)

The existence of the phrase "since" in the provisions of Article 90 paragraphs (1) and (2) of the PDRD Law, means that the appearance of tax payable if the deed has been made and signed, in the sense that the position of the timing of the implementation of the payment of BPHTB is after the deed of transfer of rights has been made and signed, it has been in accordance with the material understanding in the theory of the onset of tax debt that bases the onset of tax debt is not based on the existence of tax provisions but based on the order of the Law in a particular situation when fulfilled subjective conditions and Objective.

Furthermore, in the phrase "can only sign" in the provisions of Article 91 paragraph (1) of the PDRD Law it can be understood that PPAT is prohibited from carrying out its authority to make a deed if the taxpayer has not made payment of BPHTB or the position of BPHTB is on before the deed of transfer of rights to the land is made. Furthermore, related to PPAT that signed the deed before the payment of BPHTB get administrative sanctions as contained in the provisions of Article 93 paragraph (1), namely: where it is determined that the Land Deed Official / Notary and the Head of Office in charge of the state auction service, which violates the provisions as referred to in Article 91 paragraph (1) and paragraph (2) shall be subject to administrative sanctions in the form of a fine of $\mathrm{Rp} \mathrm{7,500,000.00} \mathrm{(seven} \mathrm{million} \mathrm{five} \mathrm{hundred} \mathrm{thousand} \mathrm{rupiah)} \mathrm{for} \mathrm{each}$ violation. However, in article 91 paragraph (3) of the PDRD Law there is a similar provision for the Head of the District /City Office where it is stated that: "The Head of Land Office can only register the Right to land or the registration of land rights transfer after the Taxpayer submits proof of tax payment".

The provision seems ambiguous, the provisions in the phrase "Notary / PPAT can only sign a deed ..." as if justifying the position of BPHTB as an absolute requirement in the creation of a deed of transfer of rights, but on the contrary with the phrase "Head of Land Office can only register the Right ....." as if it allows the occurrence of a situation where the making of a deed by a Notary / PPAT whose BPHTB has not been paid, because in the previous provision has been mentioned the terms of proof of payment BPHTB at the stage of making a deed PPAT.

The existence of some of the above articles in the view of the author has not met the legal certainty, where objective law must apply clearly in terms of substance and legal norms in order for the legislation to be fair and useful. From the description as stated above, it appears that the position of BPHTB in the process of making a deed of transfer of rights is not an absolute requirement because it is not included in the realm of material requirements or formal requirements in the creation of a deed of transfer of rights, but as a condition of procedure.

3.2 Legal Implications of BphTB's Impayment in the Process of Making a Deed of Transfer of Rights

In an activity of making a deed of transfer of rights, the formality of the deed or the date of birth or issuance of a deed from the date of creation and signing of a deed. The existence of BPHTB as a part of the conditions that must be met in a process of making a deed is very good for local government revenues. However, it certainly has a risk that when there is a situation if a transfer of rights is not carried out, it will harm the beneficiary because the tax that has been paid to the regional treasury will be difficult to withdraw, even though it has been prepared instrument arrangements that are by requesting tax restitution, but the process certainly takes a long time.

In the guide book of making deed of deed ppat by Mustofa, explained that in practice, sometimes there are urgent circumstances for example when it is paid BPHTB turns out to be very long queues while the party that will do the signing of the Deed of Sale and Purchase is impatient to wait, then in practice may be considered to venture to do the signing of the deed even though the BPHTB has not been paid as long as it is believed that BPHTB will certainly be paid on that day also because the making of the deed PPAT not stated what time it is made, only explains the day and date of the creation of the deed so it is not in question what time the payment of taxes and what time the deed is made, which must be the same day / date of payment BPHTB with the day / date of making the deed.(Mustofa, 2010)

In the provisions of Article 91 paragraph (1) of the PDRD Law, it is determined that: "The Official of the Land Deed/Notary Deed can only sign the deed of transfer of rights to land and/or buildings after the taxpayer submits proof of tax payment". The provision is closely related and in line with the provisions of Article 39 paragraph (1) letter (g) of Government Regulation No. 24 of 1997 concerning Land Registration where it is determined that PPAT refuses to make a deed, one of which is if it is not met with other conditions or violated the prohibition specified in the relevant legislation. 
The description further reinforces it in the explanation of Article 39 paragraph (1) letter (g) which states that: Examples of conditions intended in letter $g$ is for example the prohibition held by Government Regulation No. 48 of 1994 concerning Payment of Income Tax on Income from The Transfer of Land and Building Rights jo. Government Regulation No. 27 of 1996 concerning Amendments to Government Regulation No. 48 of 1994 concerning Payment of Income Tax on Income from The Transfer of Land and Buildings deed, if he is not submitted a photocopy of the income tax deposit letter in question.

Although the example in the explanation of the article is related to income tax $(\mathrm{PPh})$ on Income From the Transfer of Land and Building Rights, but of course analogously, it can be likened to the status of enforcement with the payment of BPHTB.

From the description above, it can be understood that basically the status of the sale and purchase of land rights is still valid even in the circumstances of unpaid BPHTB, as well as the validity status of the deed of transfer of rights made by the PPAT while BPHTB has not been paid, the status remains valid as long as the creation of the deed has met the material and formal requirements in the creation of the deed of transfer of rights, which is also in accordance with the validity of an agreement in accordance with article 1320 of the Civil Code and meets the requirements of the authentic deed as determined section 1868 of the Civil Code.

A deed of transfer of rights is still considered valid even though the obligation to pay the BPHTB has not been paid to the regional treasury as described above because the status of the position (Proof of payment of BPHTB) which is not as an absolute condition so as not to affect the validity status of the deed of transfer of rights, because the proof of payment of BPHTB is not included in the realm of material terms or conditions formil in the creation of the deed of transfer of rights to the land but is a part of the obligation of procedural requirements in the creation of the deed whose implementation time has been determined i.e. done before or on the same date as the date of issuance of the deed of transfer of rights (according to the phrase "from the date of creation and signing of the deed" in the provisions of Article 90 paragraph (1) of the PDRD Law concerning when owed BPHTB), so that if there is a circumstance of issuance of a deed of transfer of rights made by PPAT while the BPHTB has not been paid or late in the event of the date of issuance of the deed preceding the date of issuance of proof of payment of BPHTB, then the PPAT in question is threatened with administrative sanctions in the form of a hefty fine of Rp. 7.500.000,- (seven million five hundred thousand rupiah).

In the process of making a deed of transfer of land rights, when the parties come before the PPAT, the first will be calculated on the costs that will be charged to the parties. One of the costs that the buyer's obligation is the obligation to pay BPHTB.

In the tax collection system in full Self Assessment, the process and the right to determine already on the taxpayer's side, it is applied by filling out the Local Tax Deposit Letter (SSPD) correctly and adequately, then when the payment is made at the Payment Counter or the designated Perception Bank. One of the purposes of the establishment of a statutory regulation is to create a regularity, of course, when there is a deviation from the provisions that have been determined will have legal implications. If the deed of transfer of rights is carried out while the payment of BPHTB as one of the conditions of the procedure is not implemented will have several impacts, namely:

3.3 Implications for Land Transfer Registration

The transfer of land and building rights is closely related to legal certainty, which is characterized by evidence of the transfer of rights. As a form of force and certainty of the law of land and building ownership, any act of transfer of rights to land and or buildings must be done in accordance with applicable law. The acquisition of rights as a result of the transfer of rights must be done in writing with a deed made by the authorized official, and must be registered with the Land Office of the Regency / City in accordance with the area of the rights location. Thus, the right to land and buildings is legally on the party that acquires the right and can be defended against all parties.(Brotodiharjo, 2003)

In the provisions of Article 26 of the Agrarian Basic Law No. 5 of 1960, it is stipulated that the transfer of property rights through buying and selling can only be done where the buyer is an Indonesian citizen. If the buyer is a Foreign National, then the National Land Agency will change the Property Rights to Use Rights.

Orally made trade agreements have no legal force because the most important thing about the legal force of the agreement is the act. Based on Government Regulation No. 24 of 1997, the transfer of land and objects on it is carried out by deed of PPAT. Transfer of land from the owner to the recipient is accompanied by a juridical submission that must meet the formalities of the law including the fulfillment of the requirements, carried out through established procedures, using documents, made by and before the PPAT.(Santoso, 2013)

The transfer of land and building rights gives rise to rights and obligations for the transferees and those who accept the transfer of rights. Before the sale or transfer of land rights conducted in the presence of PPAT, then the seller must first pay Income Tax (PPh) and the buyer must first pay the Land and Buildings Acquisition Duty (BPHTB) to the Bank of perception appointed by the Government has regulated in the prevailing laws and regulations, where every person or legal entity who obtains the right to land and buildings must pay tax on the acquisition of land and buildings known as BPHTB. (Brotodiharjo, 2003) 
In the Regulation of the Minister of Agrarian Affairs No. 3 of 1997 concerning the Implementation Provisions of Government Regulation No. 24 of 1997 concerning Land Registration in Article 103 letter I the third part is regulated to fulfill the registration of transfer of rights due to the transfer of rights, namely attaching proof of payment of BPHTB. Considering these provisions, if BPHTB payment is not implemented as one of the conditions in the transfer of land rights, then the registration of the transfer of rights cannot be processed.

1. Administrative Sanctions for Land Deed Officials

Provisions on when owed BPHTB contained in article 90 paragraph (1) of the PDRD Law clearly affect the implementation of PPAT position duties. When owed BPHTB that affects the implementation of the duties of PPAT position is about the acquisition of rights through trade, exchange, grants, grants, will grants, income in the company or other legal entities, separation of rights that result in the transfer and prize. Regarding the prohibition for PPAT in the implementation of its duties to make a deed related to BPHTB (procedure) specified in article 91 paragraph (1) of the PDRD Law which is then accompanied by the threat of sanctions for violations of the provision as specified in Article 93 paragraph (1) of the PDRD Law. If the tax payable is associated with the receipt of BPHTB payment as a condition of signing the deed of transfer of rights along with the threat of sanctions against PPAT is a reasonably worrying thing, because it can potentially trigger a violation of the procedure of making a DEED PPAT, for example, the signing of the deed but the deed number, date and value of the acquisition of rights on the deed are emptied first and will be listed. At the same time, BPHTB has paid off so that the date and value of the acquisition of rights in the deed in accordance with the SSPD BPHTB.

Provisions on the existence of proof of payment BPHTB as a condition of signing the deed of transfer of rights is actually something that can be said to be somewhat excessive, moreover, accompanied by the threat of such severe sanctions against PPAT that violates the provision, namely the existence of administrative sanctions in the form of fines amounting to Rp. 7.500.000,- (seven million five hundred thousand rupiahs), when based on the provisions as stated in article 2 paragraph (1) Government Regulation No. 37 of 1998 and article 37 paragraph (1) of Government Regulation No. 24 of 1997 article 5 of the Law No. 5 of 1960, the deed of transfer of land rights made before ppat is not more than a written proof of legal action on the transfer of land rights that has been done by the parties, as well as the basis for the registration of changes in land registration data resulting from the legal action, so that the creation of this deed of transfer of rights is actually just as a condition of completing the transfer of rights that have materially occurred.

In relation to the application of self-assessment system, although PPAT is not a tax officer but to carry out its duties to make a deed ppat can force his client as a taxpayer to meet one of the requirements before the signing of the deed of transfer of rights that pays BPHTB tax, because even if PPAT signed the deed of transfer of rights while the BPHTB tax has not been paid, then the registration process of the transfer of rights at the Land Office will be rejected so that the transfer of rights cannot be processed.

In the implementation of its duties and authorities, PPAT may be subject to administrative sanctions in the form of fines if in carrying out its duties to violate the provisions governing the implementation of its position. Among these provisions are several provisions on BPHTB stipulated in the PDRD Law:

Article 91 paragraph (1) :

"The Office of the Land Deed/Notary Public can only sign the deed of transfer of Rights to Land and/or Buildings after the Taxpayer submits proof of tax payment."

Article 92 paragraph (1) :

"The Office of the Land Deed Maker / Notary and the head of the office in charge of the state auction service reported the making of the deed or minutes of auction of the Acquisition of Land and /or Buildings to the Regional Head no later than the 10th (ten) months later."

Article 92 :

Land Deed/Notary Officials and heads of offices in charge of state auction services, who violate the provisions as referred to in Article 91 paragraph (1) and paragraph (2) shall be subject to administrative sanctions in the form of fines of Rp7,500,000.00 (seven million five hundred thousand rupiahs) for each violation.

Land Deed/Notary Officials and heads of offices in charge of state auction services, who violate the provisions as referred to in Article 92 paragraph (1) shall be subject to administrative sanctions in the form of a fine of Rp250,000.00 (two hundred and fifty thousand rupiahs) for each report.

The existence of administrative sanctions is intended so that PPAT can act correctly so that PPAT products in the form of PPAT deed can be used as a basis for other legal actions in land.

Administrative sanctions are directed at the acts of violation and not against the violators. Administrative sanctions are intended for violations to be stopped. Administrative sanctions are reparatoir, i.e., to restore to its original state.(Hadjon, 2008)

\section{CONCLUSION}

The existence of the phrase "since" in the provisions of Article 90 paragraphs (1) and (2) of the PDRD Law, 
means that the appearance of tax payable if the deed has been made and signed, in the sense that the timing of the implementation of the payment of BPHTB is after the deed of transfer of rights has been made and signed, while in the phrase "can only sign" in the provisions of Article 91 paragraph (1) PDRD law can be understood that PPAT is prohibited from carrying out its authority to make a deed if the taxpayer has not made payment of BPHTB or the position of payment of BPHTB is in the before the deed of transfer rights to the land are made. From the above provisions, it appears that the position of BPHTB in the process of making a deed of transfer of rights is not an absolute requirement because it is not included in the realm of material terms or formal requirements in the creation of a deed of transfer of rights, but as a condition of procedure.

The unpaid BPHTB in the process of making a deed of transfer of land rights has implications on several things, namely:

a. Implications for the registration process of transfer of rights

The absence of BPHTB proof of payment causes the application for registration of transfer of rights at the land office cannot be further processed.

b. Administrative Sanctions for Land Deed Officials

In accordance with article 92 paragraph (1) of the PDRD Law, The Land Deed/Notary Official who violates the provisions of Article 91 of the PDRD Law where it has been determined that the concerned can only sign the deed of transfer of Land and/or Building Rights after the Taxpayer submits proof of tax payment, subject to administrative sanctions in the form of a fine of $\mathrm{Rp} 7,500,000.00$ (seven million five hundred thousand rupiahs) for each violation.

\section{REFFERENCES}

Abdulkadir, M. (1994). Hukum Harta Kekayaan. Citra Aditya Bakti, Bandung.

Brotodiharjo, S. (2003). Pengantar Ilmu Hukum Pajak, Edisi Keempat. Bandung: Refika Editama.

Budiono, H. (2007). Kumpulan tulisan hukum perdata di bidang kenotariatan. Citra Aditya Bakti.

Effendie, B. (1993). Kumpulan tulisan tentang hukum tanah. Alumni.

Hadjon, P. M. (2008). dkk, Pengantar Hukum Administrasi Indonesia. Gajah Mada University Press, Cetakan Kesepuluh.

Harahap, M. Y. (1986). Segi-Segi Hukum Perjanjian, Bandung: PT. Alumni, Hal, 4.

Latumaten, P. (2009). Kebatalan dan Degredasi Kekuatan Bukti Akta Notaris SertaModel Aktanya. Makalah Yang Disampaikan Pada Kongres XX Ikatan Notaris Indonesia Di Surabaya.

Mustofa. (2010). Tuntunan Pembuatan Akta-Akta PPAT. Karya Media, Yogyakarta.

Nurmantu, S. (2005). Pengantar perpajakan. Yayasan Obor Indonesia.

Pudyatmoko, S. (2009). Pengantar Hukum Pajak (Edisi Revisi). Yogyakrta: Andi.

Santoso, U. (2013). Pendaftaran dan Peralihan Hak atas Tanah, Cetakan III. Jakarta, Prenada Media Grup.

Siahaan, M. P. (2005). Bea Perolehan Hak Atas Tanah Dan Bangunan Teori Dan Praktek, Edisi I, Cetakan I, PT. Raja Grafindo, Jakarta.

Soedjendro, J. K. (2001). Perjanjian peralihan hak atas tanah yang berpotensi konflik: tafsir sosial hukum PPAT-Notaris ketika menangani perjanjian peralihan hak atas tanah yang berpotensi konflik. Penerbit Kanisius.

Sutedi, A. (2019). Peralihan hak atas tanah dan pendaftarannya. Sinar Grafika.

Widyaningsih, A. (2011). Hukum pajak dan perpajakan: dengan pendekatan Mind Map. 